\title{
Malaria transmission and insecticide resistance of Anopheles gambiae in Libreville and Port-Gentil, Gabon
}

\author{
Jean-Romain Mourou', Thierry Coffinet ${ }^{2}$, Fanny Jarjaval ${ }^{2}$, Bruno Pradines ${ }^{3}$, Rémi Amalvict ${ }^{3}$, Christophe Rogier $^{3}$, \\ Maryvonne Kombila ${ }^{1}$, Frédéric Pagès ${ }^{2^{*}}$
}

\begin{abstract}
Background: Urban malaria is a major health priority for civilian and militaries populations. A preliminary entomologic study has been conducted in 2006-2007, in the French military camps of the two mains towns of Gabon: Libreville and Port-Gentil. The aim was to assess the malaria transmission risk for troops.

Methods: Mosquitoes sampled by human landing collection were identified morphologically and by molecular methods. The Plasmodium falciparum circumsporozoïte (CSP) indexes were measured by ELISA, and the entomological inoculation rates (EIR) were calculated for both areas. Molecular assessments of pyrethroid knock down $(k d r)$ resistance and of insensitive acetylcholinesterase resistance were conducted.

Results: In Libreville, Anopheles gambiae s.s. S form was the only specie of the An. gambiae complex present and was responsible of 9.4 bites per person per night. The circumsporozoïte index was $0.15 \%$ and the entomological inoculation rate estimated to be 1.23 infective bites during the four months period. In Port-Gentil, Anopheles melas (75.5\% of catches) and An. gambiae s.s. S form (24.5\%) were responsible of 58.7 bites per person per night. The CSP indexes were of $1.67 \%$ for An. gambiae s.s and $0.28 \%$ for An. melas and the EIRs were respectively of 1.8 infective bites per week and of 0.8 infective bites per week. Both $k d r-w$ and $k d r-e$ mutations in An. gambiae $S$ form were found in Libreville and in Port-Gentil. Insensitive acetylcholinesterase has been detected for the first time in Gabon in Libreville.

Conclusion: Malaria transmission exists in both town, but with high difference in the level of risk. The cooccurrence of molecular resistances to the main families of insecticide has implications for the effectiveness of the current vector control programmes that are based on pyrethroid-impregnated bed nets.
\end{abstract}

\section{Background}

Malaria remains a major endemic disease in tropical areas and a significant health threat to travellers and military personnel [1]. Since 2003, French forces have implemented many studies to assess the malaria risk according to the locations of troops and the insecticide susceptibility of vectors in the field [2-4]. In Gabon, malaria is predominantly caused by $P$. falciparum and malaria transmission is perennial and was considered until today as hyperendemic [5]. Throughout the country, infections

\footnotetext{
* Correspondence: frederic_pages@yahoo.com

2UMR 6236, Unité d'entomologie médicale, IRBA antenne Marseille, Allée du Médecin Colonel Jamot, Parc du Pharo, BP 60109, 13262 Marseille Cedex 7, France

Full list of author information is available at the end of the article
}

with $P$. falciparum accounted for $30 \%$ to $50 \%$ of the consultations of children with fever between 1980s and 1990s [6,7]. In Libreville during the same period, the prevalence of P.falciparum infection and of anemia were respectively of $57 \%$ and $71 \%$ in pregnant women [8] In 2005, artemisinin-based combination therapy (ACT), insecticide- treated nets (ITNs) and intermittent preventive treatment (IPT) were freely available for children under five years old and pregnant women [9]. Since then, a decline of malaria burden has been described in Libreville both in pregnant women and children $[9,10]$. Actually, parasitaemic data in febrile children over the age of five years are questioning about both the impact on the level of transmission in Libreville and on the acquisition 
of malaria immunity in urban areas by children [11]. Libreville is probably an urban area in which a shantytown with high malaria transmission and a residential area with low transmission coexist. Unfortunately, none recent entomologic data exist on malaria transmission in Libreville or other major towns of the country. Studies conducted in the inlands showed that malaria transmission was sustained mainly by members of the Anopheles gambiae species complex and the Anopheles funestus Giles species complex $[5,12,13]$. In Libreville, a study conducted during the rainy season in 2000 showed the presence of An. gambiae s.s. molecular form $S$ and enhanced the presence of both $k d r-e$ and $k d r-w$ alleles at high frequencies in this population [14].

Malaria is a major health priority for French forces in Gabon since many years and always today. Many cases have occurred and many outbreaks have been described in the country or in returnees $[15,16]$. So most of the last clinical trials on alternative chemoprophylaxis for troops have been conducted in Gabon $[17,18]$. The vector control programs in the camps include personal protection measures (PPMs) and unit protection measures (UPMs). PPMs consist of proper use of uniforms, the application of repellent to exposed skin, the application of permethrin to battledress uniforms, and the use of insecticide-impregnated bed-nets. UPMs include environmental management, larviciding, and space spraying. Here are reported the results of a preliminary entomologic study conducted in Equatorial Africa in the two French military camp in Gabon: "camp de Gaulle" in Libreville, the capital city, and "camp N'tchorere" in Port-Gentil the economic capital city. The aim of this study was to assess the local malaria transmission risk for troops in these urban areas.

\section{Methods}

\section{Location}

This prospective and observational study was conducted from December 2006 to April 2007 in Libreville $\left(0^{\circ} 23^{\prime} 24^{\prime \prime} \mathrm{N} 9^{\circ} 26^{\prime} 59^{\prime \prime} \mathrm{E}\right)$ and in February 2007 in Port-Gentil $\left(-0^{\circ} 43^{\prime} 11^{\prime \prime} \mathrm{N} 8^{\circ} 46^{\prime} 47^{\prime \prime} \mathrm{E}\right)$. Libreville, the capital city of Gabon, is situated on the borders of the guinea gulf in West central Africa and on the border of the Komo River. The population of Libreville was estimated to be 537,540 inhabitants in 2006. The "camp de Gaulle" is situated at the north of town near the international airport $\left(0^{\circ} 26^{\prime} 32^{\prime \prime} \mathrm{N}, 9^{\circ} 25^{\prime} 38^{\prime \prime} \mathrm{E}\right)$. It is surrounded by a forested swamp on its north, with habitations including middle class and poor populations and garden markets on the other sides. Port-Gentil is the second largest city of Gabon and is situated on the Mandji Island in the delta of the Ogoué River. The population of Port-Gentil is estimated to 120600 inhabitants. The "camp N'tchorere" $\left(-0^{\circ} 42^{\prime} 57^{\prime \prime} \mathrm{N}, 8^{\circ} 45^{\prime} 37^{\prime \prime}\right)$ is situated in a periurban area and is surrounded on its west and south sides by forested or deforested areas that are liable to flooding during the rainy season and on the others sides by a few number of modern and traditional habitations.

\section{Climate}

Libreville and Port-Gentil features a tropical monsoon climate with a lengthy wet season (September through May) and a short dry season (June through August). Average temperatures remain relatively constant throughout the course of the year, with average high temperatures at around $30^{\circ} \mathrm{C}$.

\section{Field mosquito processing}

Sampling by human landing of malaria vectors was carried out both indoors and outdoors. Collectors gave prior informed consent and received anti-malaria prophylaxis and yellow fever immunization. During this survey, it was very difficult according to military constraints and the organization of the camps (modern habitat totally closed) to find indoor catching point that was representative of the indoor malaria transmission risk and acceptable for military authorities. That's why most of mosquito collections have been done outdoor. In Libreville, landing catches were performed at six points (one place indoors and five outdoors) from January 2007 to March 2007 during 23 nights and at another outdoor point during 8 nights (i.e. 146 person-nights). In Port-Gentil, human landing collections were performed in February 2007 during three nights (i.e. eight person-nights): at four points the first night (one indoor and three outdoor locations) and at two outdoor locations during the two last nights. They were sorted by genera, and anopheline and Culicinae mosquitoes were identified morphologically $[19,20]$. All mosquitoes were stored individually in numbered vials with desiccant and preserved at $-20^{\circ} \mathrm{C}$ until processing at the Medical Entomology Unit of the Institute for Biomedical research of the French Forces (IRBA), Marseille (France).

\section{Laboratory mosquito processing}

Heads and thoraces of anopheline females were tested by enzyme-linked immunosorbent assay (ELISA) for P. falciparum circumsporozoite protein (CSP) [21]. In each site, a random sample of females belonging to the Anopheles gambiae complex, together with all CSP-positive anopheline, were identified by polymerase chain reaction (PCR) at the species and molecular forms levels [22]. Molecular characterizations of the $k d r$ and ace 1 mutations were carried out on these mosquitoes as previously described $[23,24]$.

\section{Data analysis}

The human biting rate (HBR) was expressed as the number of female anopheline bites per human per night. The CSP index was calculated as the proportion 
of mosquitoes found to be positive for CSP. The entomological inoculation rate (EIR) was calculated as the product of the HBR and the CSP index of mosquitoes collected on humans. Confidence interval were calculated by the binomial exact method.

\section{Results}

\section{Libreville}

In total, 29,076 mosquitoes were caught (94.5\% Culex quinquefasciatus, 4.7\% Anopheles gambiae s.l., 0.3\% Mansonia spp., 0.2\% Culex spp., 0.2\% Aedes aegypti and $0.1 \%$ Aedes albopictus) (Table 1). Overall, the human landing catches gave an average biting rate of $9.3 \mathrm{An}$. gambiae s.l. bites per person per night. The biting rate changed all along the study according to the variations in rainfall: a decrease of rainfall during a two week period was followed by a decrease in An. gambiae s.l. biting rate in the following two weeks (Figure 1). Reported to the number of catching points indoor and outdoor, $54.8 \%$ of $A n$. gambiae s.l. biting rate occurred indoor, indicating that this species was equally endophagic as exophagic. The distribution of An. gambiae s.l. bites by hours is shown in Figure 2. The peak biting time both outdoors and indoors was between 24:00 and 6:00 a.m.: $80 \%$ of bites occurred during this period. In total, 1,368 An. gambiae s.l. collected by human landing catch were processed by ELISA for P. falciparum antigen detection. Two specimens were positive: one indoor and one outdoor. The CSP index was 0.15\% (CI95\% [0.02-0.53]). The weekly EIR was calculated as 0.1 infective bites per week for a person who did not protect himself corresponding to a DOD EIR of 1.23 infective bites per time of deployment on overseas (DOD). On the 375 specimens randomly selected and the two CSP-positive specimens, all were $A n$. gambiae s.s. molecular form S. On the 250 specimens analysed for the presence of $k d r-w$ and $k d r-e$ alleles and ace 1 mutation, two failed to amplify for the kdr allele. The genotypic frequencies are shown in Table 2. $K d r-e$ and $k d r-w$ resistance alleles were present in $\mathrm{S}$ forms with a higher frequency of the $k d r-w$ allele $(59.4 \%)$ than the $k d r-e$ allele $(40.3 \%)$. The ace1 mutation frequency was 0.4 .

\section{Port-Gentil}

In total, 6,396 mosquitoes were caught (41.3\% Mansonia spp., 27.1\% Culex spp., 24.2\% Cx quinquefasciatus, 7. 3\% An. gambiae s.l. and 0.1\% Ae. aegypti) (Table 1). Overall, the human landing catches gave an average biting rate of $58.7 \mathrm{An}$. gambiae s.l. bites per person per night. Reported to the number of catching points indoor and outdoor, $20 \%$ of $A n$. gambiae s.l. biting rate occurred indoor, indicating that this species was more exophagic. The distribution of An. gambiae s.l. bites by hours is shown in Figure 2. The peak biting time indoors was between 22:00 and 6:00 a.m. In total, three specimens on the $470 A n$. gambiae s.l. processed by ELISA were positive for P. falciparum: CSP index of 0.63\% (CI95\% [0.13-1.85]). The weekly EIR was calculated as 2.6 infective bites per week for a person who did not protect himself during the week of study. 209 specimens randomly selected and the three CSP-positive specimens were identified to species level by rDNA-PCR. Anopheles gambiae s.s. molecular form S. and Anopheles melas were the only two members of the An. gambiae complex to be identified. The S-molecular form of An. gambiae s.s. accounted for $25.5 \%$ of molecular identifications ( $\mathrm{n}=$ 54 ) and $A n$. melas accounted for $74.5 \%(\mathrm{n}=158)$. Within the three CSP-positive specimens, two were $A n$. gambiae s.s. molecular form S and one An. melas. The circumsporozoïte indexes were respectively of $1.67 \%$ (CI95\% [0.20-5.89]) for An. gambiae s.s and 0.28\% (CI95\% [0.03-1.02]) for An.melas. The respective weekly EIR for a person who did not protect himself during the week of study were of 1.8 infective bites per week for An. gambiae s.s and of 0.8 infective bites per week for An. melas. We tested all the 54 PCR-identified An. gambiae s.s and 96 of the PCR-identified An.melas for the $k d r$ and ace 1 mutations. The genotypic frequencies are

Table 1 Mosquitoes collected in the French military camps of Gabon in 2007: distribution by species and places of capture (indoor or outdoor)

\begin{tabular}{|c|c|c|c|c|c|c|c|c|c|c|c|c|}
\hline \multirow[t]{3}{*}{ Species } & \multicolumn{6}{|c|}{ "Camp de gaulle" Libreville } & \multicolumn{6}{|c|}{ “Camp N'Tchorere" Port-Gentil } \\
\hline & \multicolumn{2}{|c|}{$\begin{array}{c}\text { Indoors } \\
23 \text { person-nights }\end{array}$} & \multicolumn{2}{|c|}{$\begin{array}{c}\text { Outdoors } \\
123 \text { person-nights }\end{array}$} & \multicolumn{2}{|c|}{$\begin{array}{c}\text { Total } \\
146 \text { person-nights }\end{array}$} & \multicolumn{2}{|c|}{$\begin{array}{c}\text { Indoors } \\
1 \text { person-nights }\end{array}$} & \multicolumn{2}{|c|}{$\begin{array}{c}\text { Outdoors } \\
7 \text { person-nights }\end{array}$} & \multicolumn{2}{|c|}{$\begin{array}{c}\text { Total } \\
8 \text { person-nights }\end{array}$} \\
\hline & $n$ & $H B R$ & $n$ & $H B R$ & $n$ & $H B R$ & $n$ & $H B R$ & $n$ & $H B R$ & $n$ & $H B R$ \\
\hline An. gambiae s.l. & 255 & 11,1 & 1113 & 9,0 & 1368 & 9,3 & 19 & 19 & 451 & 64,4 & 470 & 58,7 \\
\hline Culex quinquefasciatus & 3943 & 171,4 & 23542 & 191,4 & 27485 & 188,3 & 17 & 17 & 1528 & 218,3 & 1545 & 193,1 \\
\hline Culex spp. & 2 & 0,1 & 60 & 0,5 & 62 & 0,4 & 11 & 11 & 1724 & 246,3 & 1735 & 216,9 \\
\hline Mansonia spp. & 9 & 0,4 & 64 & 0,5 & 73 & 0,5 & 48 & 48 & 2592 & 370,3 & 2640 & 330 \\
\hline Ae. aegypti & 6 & 0,3 & 55 & 0,4 & 61 & 0,4 & 1 & 1 & 5 & 0,7 & 6 & 0,7 \\
\hline Ae. albopictus & 2 & 0,1 & 25 & 0,2 & 27 & 0,2 & 0 & 0 & 0 & 0 & 0 & 0 \\
\hline Total & 4217 & 183,3 & 24859 & 202,1 & 29076 & 199,2 & 96 & 96 & 6300 & 900 & 6396 & 799,5 \\
\hline
\end{tabular}



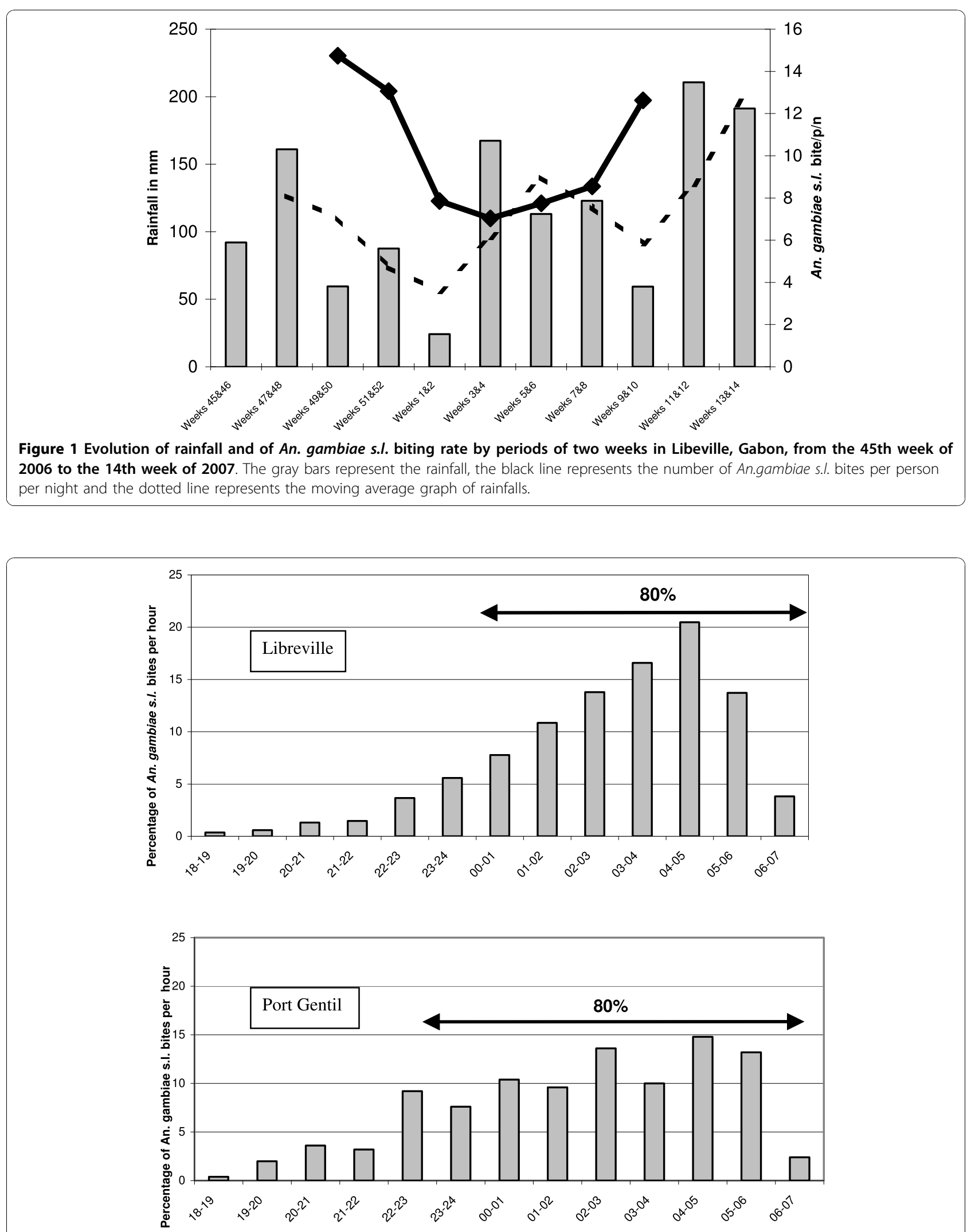

Figure 2 Distribution by hours of An. gambiae s.l. bites in the French military camps of Libreville and Port-Gentil, Gabon 2007. Gray bars represent the percentage of bites by hour of An. gambiae s.l. 
Table $2 \mathrm{Kdr}$ and AChE genotype frequencies in An. gambiae s.s. molecular form S in Libreville and Port-Gentil, 2007

\begin{tabular}{|c|c|c|c|c|c|c|c|c|c|c|c|c|}
\hline \multirow{2}{*}{\multicolumn{2}{|c|}{$\mathrm{n}$}} & \multicolumn{6}{|c|}{ Kdr genotypes } & \multirow[t]{2}{*}{$\mathrm{P} * * *$} & \multicolumn{3}{|c|}{ AChE genotypes } & \multirow[t]{2}{*}{$\mathrm{P} * * * *$} \\
\hline & & $\mathrm{S} / \mathrm{S}$ & S/Rw & $\mathrm{S} / \mathrm{Re}$ & $\mathrm{Rw} / \mathrm{Rw}$ & $\mathrm{Re} / \mathrm{Re}$ & $\mathrm{Rw} / \mathrm{Re}$ & & $S / S$ & $S / R$ & RR & \\
\hline Libreville & $250^{*}$ & 0 & 1 & 0 & 80 & 33 & 134 & & 248 & 2 & 0 & \\
\hline Port gentil & $50^{* *}$ & 0 & 1 & 0 & 21 & 3 & 25 & NS & 50 & 0 & 0 & NS \\
\hline
\end{tabular}

* Two An. gambiae s.s consistently failed to amplify for the kdr allele.

** Four An. gambiae s.s consistently failed to amplify for the kdr allele.

*** $\mathrm{Khi}^{2}$ test

****Fisher test

shown in Table 2. $K d r-e$ and $k d r-w$ resistance alleles were present in $\mathrm{S}$ forms with a higher frequency of the $k d r-w$ allele (68\%) than the $k d r$-e allele (31\%). None $K d r$ mutation was found in An.melas. Both An.gambiae s.s. and An.melas tested for insensitive AChE were found to be susceptible.

\section{Discussion}

Mosquito population densities were remarkable in the two camps both indoor and outdoor. This is particularly true in Port Gentil regarding the number of Culex and Mansonia species caught outdoors and the An.gambiae s.l. HBR of 58.7 bites per person per night. In Libreville, most of the mosquito biting rate was due to C.quinquefasciatus, a pest that breeds easily in waste water. Catches were particularly high near sanitary toilets suggesting that breeding sites were close in the septic tanks. This nuisance could probably be controlled with little effort in improving the airtightness of septic tanks. Aedes population densities were low in our study. Although night captures are not appropriate for such diurnal species, these results are concordant with a specific study conducted with BG-sentinel traps to monitor the Aedes albopictus and Ae. aegypti population in the Libreville camp [25]. Anopheles gambiae s.l. HBRs were low ranging from 2.3 to 16.8 bites per person per night during the study period. Figure 1 show the temporal variations in adult density and rainfall during the study. The curve of $A n$. gambiae s.l. HBR follow the variations of the moving average graph of the rainfall regime indicating that $A n$. gambiae density in Libreville is linked to the intensity of rainfall and probably to the number of temporary breeding sites. The assessment of the endophilic or exophilic behavior could have been biased by the scarcity of indoors collections and the difference between the camps have to be confirmed.

In Libreville, only one species of the An. gambiae complex was present: An. gambiae s.s. molecular form $S$ as already described [14]. The exclusive presence of $S$ form is consistent with the importance of rain-dependent temporary breeding sites in Libreville [26]. In Port Gentil, An. gambiae complex was represented by $A n$. melas that accounted for two thirds of catches and An. gambiae s.s. molecular form $\mathrm{S}$ for the last third.
In Libreville, An. gambiae s.s. molecular form $\mathrm{S}$ is the main malaria vector. According to the An. gambiae s.s. density-rainfall association malaria transmission is expected to be lower during the dry season from June to August. Considering the results of this survey as representative of the transmission during rainy season, an estimation of a minimal mean annual EIR of 3.7 infected bite per person per year is realistic. The present observations are consistent with the results of a metaanalysis of studies of malaria transmission in subSaharan Africa, which found a mean annual EIR of 7.1 in the city centres, with more than two thirds of the studies reporting EIRs < 4/year [27]. In Port-Gentil, $A n$. gambiae s.s. molecular form $\mathrm{S}$ and An. melas were both involved in P. falciparum transmission. If $A n$. gambiae s.s. molecular form $\mathrm{S}$ accounted for only one third of An. gambiae s.l. bites, it was responsible of two third of the $P$. falciparum transmission. Despite its lower vector competence for P. falciparum, An. melas contribution in malaria transmission in the Port-Gentil area was high as already described $[28,29]$. Extrapolating the present findings to the nine months of the rainy season and considering a low transmission level during the dry season, the average annual EIR would be at least of 100 infected bites per person per year. The level of transmission in peri-urban Port-Gentil is similar at those encountered in rural settlements [27]. The malaria transmission is totally different between the two French camps in Gabon. During a four months duty, each platoon of soldiers was based during two weeks in the N'tchorere camp and was clearly exposed to a high number of $P$. falciparum infected bites. According to the delay of incubation, a soldier that doesn't take his chemoprophylaxis would have his malaria attack in Libreville. This situation could have lead to an overestimation of malaria burden for troops in Libreville. In other hand, few cases of malaria occurred in soldiers that were permanently stationed in Port-Gentil for two years. Perhaps the high level of nuisance, nearly 800 mosquito bites per night in February 2007, enhanced the use of personal protection measures by soldiers (i.e. repellents use, bed nets use and proper wearing of battle dress) and their compliance to malaria chemoprophylaxis. $80 \%$ of bites are occurring in the second part of the night. During 
this period, most of soldiers are sleeping in mosquitoproofs buildings and are so protected. Only the outside sentinels are probably exposed to mosquito bites and to malaria vectors.

As reported previously in Gabon in Libreville and in the inlands, both kdr-w and kdr-e mutations in $A n$. gambiae molecular form $\mathrm{S}$ were present $[14 ; 30]$. Contrarily to a previous study in Libreville, $k d r$ allele was present both in Libreville and Port-Gentil, and as already described in neighbouring countries (Equatorial Guinea and Cameroon), the kdr-w allele was the most frequent both in Libreville and Port-Gentil $[31,32]$. The distribution of the $k d r$ alleles was similar in the two military camps of Port-Gentil and Libreville but there was a statistically significant difference with the historical data in Libreville $\left(\mathrm{Chi}^{2}\right.$ with $\left.2 \mathrm{df}, \mathrm{P}<10^{7}\right)$. This difference is possibly due to sampling bias or to variations in the repartition of $k d r$ alleles in An. gambiae s.s. populations between quarters in Libreville. Both $k d r-w$ and $k d r-e$ mutations have been tightly linked with DDT and pyrethroid resistance phenotypes in field populations of An. gambiae s.s [33-36]. The presence of both $k d r-e$ and $k d r-w$ alleles at high frequencies in these populations has implications for the effectiveness of the current vector control programmes, that are based on pyrethroidimpregnated bed nets both for French forces and for the Libreville or Port-Gentil inhabitants. Currently, the impact of $k d r$ on the efficacy of ITNs is unclear with contradictories studies [37-39]. Nevertheless kdr screening is still the best molecular diagnostic tool for predicting pyrethroid and DDT efficacy in preliminary studies like this one [40]. Therefore, before interventional studies, a standard WHO exposure to DDT or permethrin has to be conducted to clearly assess the resistance level and take into account the possible involvement of additional resistance mechanisms.

It was the first time that a molecular screening was conducted in Gabon to assess the presence of an insensitive acetylcholinesterase (AchE) in populations of $A n$. gambiae. A low level of insensitive AChE was detected in Libreville with an allele frequency of 0.4. None insensitive AChE was detected in Port-Gentil but there was no statistically difference in the ace 1 mutation frequency between Libreville and Port-Gentil. Complementary studies have to be conducted to monitor the possible existence of a resistance to organophosphates and carbamate insecticides in urban An.gambiae s.s. form S populations in Gabon. If carbamates remain a viable alternative in front of the low level of insensitive AchE and in the Gabonese context of a probable high resistance to pyrethroids, their extensive use alone would probably conduct to select multi-resistant specimens of An.gambiae s.s. form S in Libreville and Port-Gentil. This possibility has to be taking in account before implementing vector control programmes both in military camps and in towns. The use of a combination of pyrethroids and organophosphates in mixture, mosaic or in parallel on different supports has been proposed against pyrethroid-resistant malaria vectors [41-43]. A new mosaic long-lasting insecticidal net developed to control wild pyrethroid resistant An. gambiae has shown no benefits compared to classical long-lasting insecticidal nets $[44,45]$.

According to literature, this was the first time that entomological studies on malaria transmission were conducted in the main towns of Gabon, which represent more than $50 \%$ of the total population. Malaria transmissions exist in both towns but with high difference in the level of risk. In urban areas, malaria transmission is highly focused and a single study in one area of a town is not sufficient to assess the global level of transmission. And one should not minimize the possible impact of the vector control programme implemented in the camps all year round. In Libreville, the risk is comparable to other big African cities, but seems very low according to the equatorial situation and the previously described hyperendemic transmission. Nevertheless, these results are concordant with the clinical statements made by physicians and researchers in Libreville that all concluded to a decrease in malaria transmission since 2000 in Libreville [9-11]. In Port-Gentil, the level of transmission is high but is probably not representative of the current situation in all parts of Port-Gentil. Anopheles melas is clearly involved in malaria transmission in Port-Gentil, but further studies in different parts of Libreville are necessary to understand its involvement or not. Until today, molecular screenings of resistance in Gabon have only concerned kdr mutation. Here is the first report of insensitive acetylcholinesterase in Gabon. This paper highlights the worrying level of pyrethroids resistance of $A n$. gambiae s.s. for most of $50 \%$ of Gabon's population. There is a lack of entomological data to understand the dynamic of urban malaria in Gabon. Further studies have to been conducted in different areas of theses towns including central and peripheral districts, coastal and inland districts, modern and traditional districts. The situation of insecticide resistance has to be clarified in using molecular tools and insecticide bioassays in different districts of each town.

\section{Conflict of interest}

The authors declare that they have no competing interests.

\section{Authors' contributions}

JRM was responsible for the supervision of data collection, analysis, interpretation and production of the final manuscript and revisions. TC contributed to the supervision of data collection, the data analysis, interpretation and production of final manuscript. FJ contributed to the supervision of data collection, to the data analysis. BP contributed to the 
supervision of data collection, to the data analysis, interpretation and production of final manuscript. RA FJ contributed to the supervision of data collection, to the data analysis. CR contributed to overall scientific management, analysis, interpretation and preparation of the final manuscript and revisions. MK contributed to overall scientific management, analysis, interpretation and preparation of the final manuscript and revisions. FP was responsible for overall scientific management, analysis, interpretation and preparation of the final manuscript and revisions. All authors have read and approved the final manuscript.

\section{Acknowledgements}

We thank the collector's team for commitment in the fieldwork as well as the French military authorities in Libreville and Port Gentil.

Financial support: This study was supported by Délégation Générale pour I'Armement (grant 02CO011, no. 010808) with the valuable assistance of the veterinary Chief Claire Dane.

\section{Author details}

'Département de Parasitologie-mycologie, Faculté de médecine, Université des Sciences de la Santé, B.P. 4009 Libreville Gabon. ${ }^{2}$ UMR 6236, Unité d'entomologie médicale, IRBA antenne Marseille, Allée du Médecin Colonel Jamot, Parc du Pharo, BP 60109, 13262 Marseille Cedex 7, France. ${ }^{3}$ UMR 6236, Unité de parasitologie, IRBA antenne Marseille, Allée du Médecin colonel Jamot, parc du Pharo, BP 60109, 13262 Marseille Cedex 7, France.

Received: 8 July 2010 Accepted: 11 November 2010

Published: 11 November 2010

\section{References}

1. Pagès F, Faulde M, Orlandi-Pradines $E$, Parola P: The past and present threat of vector-borne diseases in deployed troops. Clin Microbiol Infect 2010, 16:209-224.

2. Girod R, Orlandi-Pradines E, Rogier C, Pagès F: Malaria transmission and insecticide resistance of Anopheles gambiae (Diptera: Culicidae) in the French military camp of Port-Bouet, Abidjan (Cote d'Ivoire): implications for vector control. J Med Entomol 2006, 43:1082-1087.

3. Orlandi-Pradines E, Rogier C, Koffi B, Jarjaval F, Bell M, Machault V, Pons C, Girod R, Boutin JP, Pagès F: Major variations in malaria exposure of travellers in rural areas: an entomological cohort study in western Côte d'Ivoire. Malar J 2009, 8:171.

4. Pagès $F$, Texier $G$, Pradines $B$, Gadiag L, Machault $V$, Jarjaval F, Penhoat $K$, Berger F, Trape JF, Rogier C, Sokhna C: Malaria transmission in Dakar: a two-year survey. Malar J 2008, 7:178.

5. Elissa N, Karch S, Bureau P, Ollomo B, Lawoko M, Yangari P, Ebang B, Georges AJ: Malaria transmission in a region of savanna-forest mosaic, Haut-Ogooué, Gabon. J Am Mosa Control Assoc 1999, 15:15-23.

6. Richard-Lenoble D, Kombila M, Chandenier J, Engohan E, Gannier M, Dubourg C: Malaria in Gabon. I. Study of 500 children with fever in Libreville. Bull Soc Pathol Exot Filiales 1986, 79:284-7.

7. Richard-Lenoble D, Kombila M, Chandenier J, Gay F, Billiault X, Nguiri C, Martz M, Boyer F, Bauzou M: Malaria in Gabon. 2. Evaluation of the qualitative and quantitative prevalence of parasites in the total school and preschool population of the country. Bull Soc Pathol Exot Filiales 1987, 80:532-542.

8. Bouyou-Akotet MK, lonete-Collard DE, Mabika-Manfoumbi M, Kendjo E, Matsiegui PB, Mavoungou E, Kombila M: Prevalence of Plasmodium falciparum infection in pregnant women in Gabon. Malar J 2003, 2:18,

9. Ramharter M, Schuster K, Bouyou-Akotet MK, Adegnika AA, Schmits K, Mombo-Ngoma G, Agnandji ST, Nemeth J, Nzenze Afène S, Issifou S, Ndombi Onnas I, Kombila M, Kremsner PG: Malaria in pregnancy before and after the implementation of a National IPTp program in Gabon. Am J Trop Med Hyg 2007, 77:418-422.

10. Bouyou-Akotet MK, Mawili-Mboumba DP, Kendjo E, Mabika-Mamfoumbi M, Brice Ngoungou E, Dzeing-Ella A, Pemba-Mihindou M, Ibinga E, EfameEya E, MCRU team, Planche T, Kremsner PG, Kombila M: Evidence of decline of malaria in the general hospital of Libreville, Gabon from 2000 to 2008. Malar J 2009, 8:300.

11. Bouyou-Akotet MK, Dzeing-Ella A, Kendjo E, Etoughe D, Ngoungou EB, Planche T, Koko J, Kombila M: Impact of Plasmodium falciparum infection on the frequency of moderate to severe anaemia in children below 10 years of age in Gabon. Malar J 2009, 8:166.
12. Elissa N, Migot-Nabias F, Luty A, Renaut A, Touré F, Vaillant M, Lawoko M, Yangari P, Mayombo J, Lekoulou F, Tshipamba P, Moukagni R, Millet P, Deloron P: Relationship between entomological inoculation rate, Plasmodium falciparum prevalence rate, and incidence of malaria attack in rural Gabon. Acta Trop 2003, 85:355-61.

13. Sylla EH, Kun JF, Kremsner PG: Mosquito distribution and entomological inoculation rates in three malaria-endemic areas in Gabon. Trans $R$ SOC Trop Med Hyg 2000, 94:652-6.

14. Pinto J, Lynd A, Elissa N, Donnelly MJ, Costa C, Gentile G, Caccone A, Do Rosario VE: Co-occurrence of East and West kdr mutations suggests high levels of resistance to pyrethroid insecticides in Anopheles gambiae from Libreville, Gabon. Med Vet Entomol 2006, 20:27-32.

15. Meignan F, Falcot J, Carret JL, Thierry J: Drug resistance of Plasmodium falciparum malaria in Equatorial Africa. A propos of cases observed at a military unit stationed in Gabon. Bull Soc Pathol Exot Filiales 1987, 80:443-446.

16. Nicolas X, Nicolas F, Gorge O, Perret JL, Touze JE: Malaria in expatriates in Africa. 154 cases. Clinical problems and therapeutic difficulties. Presse Med 1997, 26:158-160.

17. Sarrouy J, Cellier C, Migliani R, Todesco A, Favier G, Linden L, Pull J, Pascal B, Baudon D, Delolme H: Chemoprophylaxis of Plasmodium falciparum malaria by a combination of $100 \mathrm{mg}$ of chloroquine and $200 \mathrm{mg}$ of proguanil per day in a zone III of chloroquine resistance (Gabon). Study of 431 French soldiers. Bull Soc Pathol Exot 1999, 84:80-93.

18. Pagès F, Boutin JP, Meynard Jb, Keundjian A, Ryfer S, Giuriato L, Baudon D Comparison of doxycycline monohydrate salt vs chloroquine-proguanil in malaria chemoprophylaxis. Trop Med Int Health 2002, 7:919-924.

19. Gillies MT, Coetzee M: A supplement to the anophelinae of Africa south of the Sahara (Afrotropical region) The South African Institut for Medical Research No. 55, Johannesburg, South Africa; 1987.

20. Edwards FW: Mosquitoes of the Ethiopian Region. III.- Culicine adults and pupae London: British Museum (Natural History); 1941.

21. Burkot TR, Zavala F, Gwadz RW, Collins FH, Nussenzweig RS, Roberts DR: Identification of malaria infected mosquitoes by a two-site enzymelinked immunosorbent assay. Am J Trop Med Hyg 1984, 33:227-231.

22. Fanello C, Santolamazza F, Della Torre A: Simultaneous identification of species and molecular forms of the Anopheles gambiae complex by PCRRFLP. Med Vet Entomol 2002, 16:461-464.

23. Lynd A, Ranson H, MCCall PJ, Randle NP, Black WC, Walker ED, Donnelly MJ: A simplified high-throughput method for pyrethroid knock-down resistance $(k d r)$ detection in Anopheles gambiae. Malar J 2005, 4:16.

24. Weill M, Malcolm C, Chandre F, Mogensen K, Berthomieu A, Marquine M, Raymond $\mathrm{M}$ : The unique mutation in ace-1 giving high insecticide resistance is easily detectable in mosquito vectors. Insect Mol Biol 2004, 3:1-7.

25. Pagès $F$, Peyrefitte $C N$, Toungve $M$, Jarjaval $F$, Brisse $S$, Iteman I, Gravier $P$, Nkoghe D, Grandadam M: Aedes albopictus mosquito: the main vector of the 2007 Chikungunya outbreak in Gabon. PLOS ONE 2009, 4:e4691.

26. Touré YT, Petrarca V, Traore SF, Coulibaly A, Maiga HM, Sankaré O, Sow M, Di Deco MA, Coluzzi M: The distribution and inversion polymorphism of chromosomally recognized taxa of the Anopheles gambiae complex in Mali, West Africa. Parassitologia 1998, 40:477-511.

27. Robert V, Macintyre K, Keating J, Trape JF, Duchemin JB, Warren M, Beier JC: Malaria transmission in urban subsaharian Africa. Am J Trop Med Hyg 2003, 68:169-176.

28. Fontenille $D$, Lochouarn $L$ : The complexity of the malaria vectorial system in Africa. Parassitologia 1999, 41:267-71.

29. Coffinet T, Mourou JR, Toto JC, Pradines B, Jarjaval F, Amalvict R, Kombila M, Carnevale P, Pagès F: First record of Aedes albopictus (Skuse) from Gabon. J Am Mosq Control Assoc 2007, 23:471-472.

30. Santolamazza F, Calzetta M, Etang J, Barrese E, Dia I, Caccone A, Donnelly MJ, Petrarca V, Simard F, Pinto J, della Torre A: Distribution of knock-down resistance mutations in Anopheles gambiae molecular forms in west and west-central Africa. Malar J 2008, 7:74.

31. Etang J, Fonjo E, Chandre F, Morlais I, Brengues C, Nwane P, Chouaibou M, Ndjemai H, Simard F: Short report: First report of knockdown mutations in the malaria vector Anopheles gambiae from Cameroon. Am J Trop Med Hyg 2006, 74:795-797.

32. Moreno M, Vicentez JL, Cano J, Berzosa PJ, de Lucio A, Nzambo S, Bobuakasi L, Buatiche JN, Ondo M, Micha F, Do Rosario VE, Pintoz J, 
Benito A: Knockdown resistance mutations (kdr) and insecticide susceptibility to DDT and pyrethroids in Anopheles gambiae from Equatorial Guinea. Trop Med Int Health 2008, 13:430-433.

33. Chandre F, Darriet F, Manga L, Akogbeto M, Faye O, Mouchet J, Guillet P: Pyrethroid cross resistance spectrum among populations of Anopheles gambiae s.s. from C6te d'Ivoire. J Am Mosq Control Assoc 1999, 15:53-59.

34. Donnelly MJ, Corbel V, Weetman D, Wilding GS, Williamson MS, Black WC IV: Does Kdr genotype predict insecticide resistance phenotype in mosquitoes? Trends Parasitol 2009, 25:213-219.

35. Ranson $\mathrm{H}$, Jensen $B$, Vulule JM, Wang $X$, Hemingway J, Collins FH: Identification of a point mutation in the voltage-gated sodium channel gene of Kenyan Anopheles gambiae associated with resistance to DDT and pyrethroids. Insect Mol Biol 2000, 9:491-497.

36. Reimer L, Fonjo E, Patchoke S, Diallo B, lee Y, Ng A, Ndjemai HM, Atangana J, Traore SF, Lanzaro G, Cornel AJ: Relationship between kdr mutation and resistance to pyrethoid and DDT insecticides in natural populations of An. gambiae. J Med Entomol 2008, 45:260-266.

37. Darriet F, N'guessan R, Koffi AA, Konan L, Doannio JM, Chandre F, Carnevale P: Impact of pyrethrin resistance on the efficacity of impregnated mosquito nets in the prevention of malaria: results of tests in experimental cases with deltamethrin SC. Bull Soc Pathol Exot 2000, 93:131-4.

38. Kolaczinski JH, Fanello C, Herve JP, Conway DJ, Carnevale P, Curtis CF: Experimental and molecular genetic analysis of the impact of pyrethroid and non-pyrethroid insecticide-impregnated bednets for mosquito control in an area of pyrethroid resistance. Bull Entomol Res 2000, 90:125-132.

39. N'Guessan R, Corbel V, Akogbéto M, Rowland M: Reduced efficacy of insecticide-treated nets and indoor residual spraying for malaria control in pyrethroid resistance area, Benin. Emerg Infect Dis 2007, 13:199-206.

40. Sharp B, Ridl FC, Govender D, Kuklinski J, Kleinschmidt I: Malaria vector control by indoor residual insecticide spraying on the tropical island of Bioko. Equatorial Guinea. Malar J 2007, 6:52.

41. Asidi AN, N'Guessan R, Koffi AA, Curtis CF, Hougard JM, Chandre F, Corbel V, Darriet F, Zaim M, Rowland MW: Experimental hut evaluation of bednets treated with an organophosphate (chlorpyrifos-methyl) or a pyrethroid (lambdacyhalothrin) alone and in combination against insecticide-resistant Anopheles gambiae and Culex quinquefasciatus mosquitoes. Malar J 2005, 4:25.

42. Djènontin $A$, Chabi J, Baldet $T$, Irish $S$, Pennetier $C$, Hougard JM, Corbel V, Akogbéto $\mathrm{M}$, Chandre F: Managing insecticide resistance in malaria vectors by combining carbamate-treated plastic wall sheeting and pyrethroid-treated bed nets. Malar J 2009, 8:233.

43. Pennetier C, Costantini C, Corbel V, Licciardi S, Dabiré RK, Lapied B, Chandre F, Hougard JM: Mixture for controlling insecticide-resistant malaria vectors. Emerg Infect Dis 2008, 14:1707-1714.

44. Corbel V, Chabi J, Dabiré RK, Etang J, Nwane P, Pigeon O, Akogbeto M, Hougard JM: Field efficacy of a new mosaic long-lasting mosquito net (PermaNet 3.0) against pyrethroid-resistant malaria vectors: a multi centre study in Western and Central Africa. Malar J 2010, 9:113.

45. Tungu P, Magesa S, Maxwell C, Malima R, Masue D, Sudi W, Myamba J, Pigeon O, Rowland M: Evaluation of PermaNet 3.0 a deltamethrin-PBO combination net against Anopheles gambiae and pyrethroid resistant Culex quinquefasciatus mosquitoes: an experimental hut trial in Tanzania. Malar J 2010, 9:21.

doi:10.1186/1475-2875-9-321

Cite this article as: Mourou et al: Malaria transmission and insecticide resistance of Anopheles gambiae in Libreville and Port-Gentil, Gabon. Malaria Journal 2010 9:321.

\section{Submit your next manuscript to BioMed Central and take full advantage of:}

- Convenient online submission

- Thorough peer review

- No space constraints or color figure charges

- Immediate publication on acceptance

- Inclusion in PubMed, CAS, Scopus and Google Scholar

- Research which is freely available for redistribution

Submit your manuscript at www.biomedcentral.com/submit
Biomed Central 